\title{
The Implementation of Student Team Achievement Division and Group Investigation Teaching Approaches in Translation 2
}

\author{
Yuli Kuswardani \\ Universitas PGRI Madiun \\ Madiun, Indonesia \\ ikuswardaniae@gmail.com
}

\author{
Rengganis Siwi Amumpuni \\ Universitas PGRI Madiun \\ Madiun, Indonesia \\ Rengganis_kiswanto@yahoo.com
}

\begin{abstract}
This research is a research on the importance of Student Team Achievement Division and Group Investigation as appropriate teaching approaches to solve problems existing in translation 2 at Department of English Teaching Universitas PGRI Madiun. Translation is an interdisciplinary study in which other disciplines play important role. Besides, translation is a study, skill, and art. Suitable teaching approach is required to study translation. This study aims to describe the application of Student Team Achievement Division and Group Investigation in translation 2. The samples in this research are seventh semester students and translator 2 lecturer who is a researcher in this study as well. Data source derived from observation, in-depth interviews, and documentation. Data analysis was done with the analysis of interactive models. There are two main activities in the application of Student Team Achievement Division and Group Investigation in translation 2. The first activity that is translating texts in the study groups include analysis, transferring, and restructuring. The members cooperate and overcome existing problems in analyzing texts, looking for the equivalences, and restructuring the translation result. The second activity, namely the presentation of the translation results. Presentation of translation results is done through several steps, namely presentation step-answering and questioning step-revision step-presentation of revision result stepfinal result step. The students who have lower ability in translating text became more enthusiastic because they shared problems with other member who have higher ability so there was improvement of students' interests and quality of translation.
\end{abstract}

Keywords-Student Team Achievement Division, Group Investigation, Translation 2

\section{INTRODUCTION}

Translation is not a simple and easy task. To translate, a specific expertise is required to produce a good (accurate, readable, natural) translation. Kridalaksana [1] defines translation as transferring message from the source language into the target language by first revealed its meaning, then as far as possible maintain the style, given that the style of the translation language is one of the important aspects that need to be considered in any activity to translate.

Gross [2] suggests process of translation which includes three phases, namely analysis, transferring, and restructuring. At this stage of the analysis, the translator analyzes texts in the source language; understand the content of the text. Understanding the meaning of these include understanding intralinguistic factors of, such as headings, paragraphs, collocation, idiom and so forth [3]. The translator must also observe the extralinguistic factors, such as culture and the context of a situation which aspects influenced the text. The next stage is the stage of transfer. This stage is a stage when translator tries to find equivalents of the text in the source language into the target language. Translators can proceed to the next stage or restructuring. In this stage, the translators restructure the sentences in order the sentences conform to target language rule.

It is not an easy thing to teach and study translation, both for the students and teachers. In the process of teaching and learning translation 2 there are some problems that arise. By the time the students translate, the students having a lot of difficulty, i.e. at a time when students perform analysis, transferring, and restructuring. At this stage of the analysis, students have difficulty in understanding the context of a source language text (text translated) whereas it is a very important first step in translating. Soemarno [3] says: "Clearly the understanding of word and sentence meaning involves intralinguistic and extralinguistic factor". This statement implies that to understand text, translator should analyze intralinguistic and extralinguistic factors. Students should be able to analyze sentence structure, collocation, idiomatic expressions, and style used, The majority of students have lower ability in analyzing text.

Other difficulties experienced by students when translating took place on the stage of the transferring. At this stage, students should be able to find suitable equivalents for all of the words, phrases, clauses, and sentences, and even look for a counterpart to the entire discourse. Students often have difficulty in finding equivalents in the target language. This is due to the ability of the students in using the dictionary which has not been so good. Students are less able to distinguish a word functions in relation to other words in a sentence so students often get difficulties in determining equivalent of certain words.

Furthermore, students get difficulty in restructuring phase, for example, when the student must decide to find the equivalent of a draft or its translation in accordance with the rules of the target language. Student's mastery of language and culture is still not good. On the other hand, translating is not 
merely replacing one word into another word. Newmark [4] states, "Translation is a craft consisting in the attempt to replace a written message and or statements in one language by the same message and/or statement in another language." In this definition, Newmark requires expertise or skills as something required in translation.

To resolve the problem in the process of teaching and learning in translation 2, then the teaching approach that comply with the conditions of the students and expected to be the solution to overcome the problem is required. It is needed the teaching approach that provides access for students to actively construct their own knowledge through a process of invention and of thinking of their own that emphasizes the importance of learning together with mutual help to each other as one team. Student Team Achievement Division and Group Investigation are teaching approaches that can be combined to be applied in translation 2 in order to be a solution for a problem that is faced by the students.

According to Gross [2], Student Team Achievement Division is a technique in the teaching learning process that is effective to increase students motivation and enthusiasm, and it can develop their responsibility in their own group. Gross [2] states Student Team Achievement Division as one type of cooperative learning model, in which students are placed in teams according to the level of learning achievement and gender. Teaching and learning activities are initiated by passing on learning objectives, delivery of material, group activities, and quizzes. Furthermore, it is said that Student Team Achievement Division has consistently been shown to be among the most simple and effective cooperative learning methods [5].

Isjoni [6] states that Student Team Achievement Division applied through five stages which include: stage of the presentation of the material (i.e. the stage where teachers start by conveying the indicators to be achieved and motivate student's curiosity about the material to be learned, give the perception to warn students against the material prerequisites that have been studied so students can connect the material to be presented with the knowledge that has been owned); stage of group work (at this stage each student was given a sheet of material that will be studied, students share assignments, help each other give a settlement so that all group members understand the material covered, the teacher acts as a facilitator and motivator); iindividual test stage (i.e. to know the extent to which the success of learning has been achieved, held individually, tests on the material covered; stage of development of the individual (the score calculation is calculated based on the initial score, the calculation is intended so that students are encouraged to gain the best achievement in accordance with its ability)

Larson [10] splits the step-by-step implementation of the model of group investigation as follows: choose a topic (students choose a special subtheme be a common problem that is usually set by the teacher, next the students are organized into groups that are oriented tasks); cooperative planning (students and teachers plan learning procedures, tasks and specific purpose that is consistent with the subtheme that has been selected); implementation (students apply the plans that they have developed, learning activities involve extensive skills and activities and direct students in different types of learning resources both within and outside of school, teachers offer help and follow the progress of each group); analysis and synthesis (students analyze and synthesize information obtained and plan how the information was summarized and presented as material for the presented at the whole class); final results presentation (all his research group presents the results to the entire class with the goal of keeping the other students are mutually engaged each other in their work and gain a broad perspective, the presentation was coordinated by the teacher); evaluation (evaluation done can be either individual or group assessments).

Based on the background of the problems and explanation of the theories described above, the formulation of the problem in this research can be stated as follows: how is the implementation of Student Team Achievement Division and Group Investigation in translation 2?

\section{METHODS}

This research is qualitative research with qualitative approach. The method used is descriptive qualitative method because the researchers describe the implementation of Student Team Achievement Division and Group Investigation in the process of teaching and learning translation 2. The research design used is case study. The type of case study used is singlecase design.

The source of the data in this study are 7 th semester students, the results of the interview contains the student response about implementation of Student Team Achievement Division and Group Investigation in translating on the teaching and learning of translation 2, and documents in the form of the results of translation students, lesson plan, list the name of the student, and the student value list.

This research uses purposive sampling. The sample were chosen by some considerations namely, different level of intelligence, skills, and backgrounds.

The techniques of data collection in this research are observation, interview, and documentation. In observation, researchers play an active role in the implementation of Student Team Achievement Division and Group Investigation. First researcher is a lecturer of translation 2. Interview was conducted to 7 th semester students to gain data about the advantages and disadvantages of Student Team Achievement Division and Group Investigation implementation in the process of teaching and learning translation 2 Documentation is done by researchers to identify document type in order to find out if these documents provide information to answer the problem formulation or not. Then check if the documents are accurate, complete and useful.

In this study, the way used to increase validity is triangulation. Researchers apply a triangulation of sources, method, and investigators. Triangulation of sources is used to compare the data obtained with different sources, namely documents, interviews, and observation results. Triangulation of method used to obtain data with different techniques, i.e., interview, observation, and 
documentation. In addition, investigators triangulation was used by means of comparing the results of the analysis done by first researcher and second researcher.

This research uses interactive analysis developed by Miles and Huberman [7]. In this study, the steps are: reducing data, displaying data, and taking summary and verification.

\section{RESULT AND DISCUSSION}

Learning activities observed in translation 2 are group discussion to translate the text and group presentation to present translation results.

At the first meeting, the lecturer explained to students about the implementation of Student Team Achievement Division and Group Investigation on translation 2. Lecturer formed study groups in class. There were 5 groups were formed, each group consists of students who have great, medium, and low ability.

There were two main tasks of the students either individually or collectively in study groups. Individual task of students was translating text in group discussion but reporting the results of translation in workbook. Collective task was presentation of translating results, together with members of study group for one-time presentation to one title. The texts were different for each group. The texts given by a lecturer to be translated by each group are The Mask Maker, Genetic Diversity, In Praise of Education, Silas Marner, and The Question of Translation and Translation Studies.

Students translated the text in the study group's discussion on the schedule of translation 2 but because the time available was not enough to complete their tasks of translating the text then the lecturer gave instruction to extend it beyond the translation 2 schedule. The results of the interviews show that the students continue to work on the task of translating the text in the library or in the house. Students were also given the opportunity to consult the results of translation as well as the difficulties that students met at the lecturer outside the lecture schedule.

The results of individual translation were written in striped foolscap. Format was determined by the lecturer, in a table containing 4 columns. The first column contains the number of the sentences. The second column contains the text of the source language that must be translated. The third column contains the text of the target language in Indonesian language. The fourth column was the blank column provided to make revisions as a result of class discussion. Individual translation results were collected and signed by lecturer. They were, then, given back to the student to be analyzed through first presentation and class discussion.

Translation result to be presented as the collective tasks was similar to that of individual work but it made in power point format and consulted to lecturer before it presented.

At first presentation, the performer group presented their translation. It was presentation step. Students in other groups required to provide feedback on the result of the translation of group performer. The response could be a question, a disclaimer, statements that support the answers of performer, corrections and suggestions to the weaknesses of the translation results presented. Lecturer did assessment of student responses to other groups. This concerns the assessment of the quality of the content of the response. In addition lecturer straightened performer incorrect answers and straightened out responses from students who are less relevant to the presentation of the material. It was answering and questioning step.

During the presentation the student of other group was obligated to make revisions of their individual translation. The work was collected back to the lecturer to sum up in lecturer notes. It was revision step.

The following week, the performer group presented the revision of translation in the presentation of revision result step. Translation of individual revision returned and handed out on students to be analyzed again in second presentation and class discussion.

Students in another group compared the revision of translation presented with their individual translation revision respectively. Later the performer group and other groups of students together with lecturer discussed the revision of translation presented in the class discussion. The lecturer and students discussed the results of translation in terms of accuracy, naturalness, readability. Another group of students and lecturer asked questions or gave feedback about the translation revision. The performer group was obliged to respond to questions, criticisms, or suggestions from other students and lecturer. One by one each part of the sentence of translation revision reviewed. During this discussion performer group made second revisions in the translation results in power point presented. Another student of other study groups also made the second revision of the translation in the worksheet respectively.

Second revision of the translation of performer group and other groups of students gathered again on the lecturer. Translation revision worksheet was signed and summed up in lecturer notes to be evaluated at the end of the semester to see the development of the ability of each student in translating text.

The following week, a day before the scheduled of translation 2 lecturer returned the revision of the translation. A performer group presented the second translation revision. That was result determination step. The performer group, other students and lecturer determined the final translation result in terms of accuracy, naturalness, and readability.

The score of the collective translation task presented was the same because the task was carried out by all members of the group. The score of the mastery of the material and the presentation of each member in the same group was different and was determined by the ability of each student in the presentation of the results of the translation. The score of the task of translating of each student was individually different.

Notes about the individual work of students were evaluated at the end of the semester by lecturer to know the development of the ability of students in translating text and to find out the progress of students in translating so that notes can be used as a parameter to determine the final score of the students. Presentation results in power point that was also 
collected on the lecturer in the form of soft file were saved as a lecturer document.

The implementation of Student Team Achievement Division and Group Investigation in translation 2 can improve students' ability to translate. Students were more active to gain the theories of translation and information related to the material of the text being translated. In the first step of translating process analyzing, the lecturer also finds that students' ability to translate is better than at the beginning of the class. They share their problems to analyze the source language sentence structures with other students and they create some ways by themselves to make the analysis is easier. In the second step of translating process namely transferring, from interview results, it can be seen that students are more capable to use dictionaries. Students try to determine the meaning of words based on the parts of speech described in dictionaries. Searching information from encyclopedia or other sources made students know the way to find equivalences of untranslatable concepts in the translation result. In the third step of translating process namely restructuring, students consult their translation results to other members of same study group, but sometimes they also share problems to the members of other study groups. The students build cooperation with each other. This research result is in line with the research results held by Yusuf, et al. [8] which shows that STAD technique is considered suitable to be implemented in teaching reading to EFL learners. Other research result also shows that implementation of "group investigation cooperative learning" oriented contextual can improve students activeness in learning science [9].

It can be summed up that implementation of Student Team Achievement Division and Group Investigation in translation 2 brings some positive impacts. It can increase students' interest to translation, ability to translate, responsibility to individual and collective tasks, and motivation to be active in class. Hopefully, the results of this study can give contribution to the translation lecturers who also face same problems in teaching and learning process of translation.

\section{REFERENCES}

[1] H. Kridalaksana, Kamus Linguistik. Jakarta: Gramedia, 1993.

[2] P.Gross, Teaching Learning activity for students at senior high school. London: harper collins publisher, 1991.

[3] T. Soemarno, The Problems of Culture in Translation Munas IV dan Semnas II HIMABS1I 24-26 September Universitas Sanata Dharma Yogyakarta, 2001.

[4] P. Newmark, Approaches to Translation. Oxford: Pergamon Press, 1981.

[5] G. Ghaith," Correlates of the Implementation of the STAD Cooperative Learning Method in the English as a Foreign Language Classroom", International Journal of Bilingual Education and Bilingualism, 7:4, 279294, DOI: 10.1080/13670050408667813, 2004.

[6] Isjoni, Cooperative Learning: Mengembangkan Kemampuan Belajar Berkelompok. Bandung: Alfabeta, 2007.

[7] M.B. Miles, and A.M. Hubermen, Qualitative Data Analysis. Thousand Oaks: Sage Publications, 1994.

[8] Y.Q. Yusuf, Y. Natsir, L. Hanum, "A Teacher's Experience in Teaching with Student Teams-Achievement Division (STAD) Technique", International Journal of Instruction, July 2015, Vol.8, No.2 e-ISSN: 1308-1470, www.e-iji.net p-ISSN: 1694-609X, 2015.
[9] H. Nasrudin and U. Azizah, "Improvement Thingking Skills And Scientific Attitude Using The Implementation Of "Group-Investigation Cooperative Learning" Contextual Oriented At Acid, Base And Salt Topic In Junior High School, Proceedings of The 4th International Conference on Teacher Education; Join Conference UPI \& UPSI. Bandung, Indonesia, 8-10 November 2010.

[10] M.L. Larson, Penerjemahan Berdasar Makna (Edisi terjemahan oleh Kencanawati Taniran). Jakarta: Arcan, 1989. 